Gefässchirurgie $2019 \cdot 24: 21-26$ https://doi.org/10.1007/s00772-018-0473-x Published online: 16 November 2018 (c) The Author(s) 2018 CrossMark

\author{
B. Sigvant ${ }^{1,2} \cdot K^{\prime}$ Mani ${ }^{1} \cdot$ M. Björck $^{1}$ \\ 'Department of Surgical Sciences, Uppsala University, Uppsala, Sweden \\ ${ }^{2}$ Department of Surgery, Karlstad Hospital, Karlstad, Sweden
}

\title{
The Swedish vascular registry Swedvasc 1987-2018
}

\section{1 years of quality improvement and research}

\section{Electronic supplementary material}

The online version of this article (https:// doi.org/10.1007/s00772-018-0473-x) includes a publication list of all papers published in the name of Swedvasc. The article and supplementary material are available at http://www.springermedizin.de/ gefaesschirurgie. The additional material can be found at the end of the article under "supplementary material".

Clinical quality registers are important to monitor quality of care, guide quality improvement projects, describe patterns of treatment and outcomes over time, and as a data source for research. Clinical registries have shown an impact on health outcome [1,2]. Data collection with frequent reports and audits improve clinical practice, core results and reduce regional differences. Additionally, data may be used to compare treatment practices internationally. Awareness of the practice patterns and outcome can aid clinicians in benchmarking their clinical activity against others and using the available data to influence healthcare authorities to support improvement initiatives $[3,4]$.

\section{Development of the first population-based vascular surgical registry}

Sweden has a long history of surgical registries. As long ago as 1798 Olof af Acrel, the founder of scientific surgery in Sweden, suggested registering clinical parameters of all treated patients. In the field of vascular surgery, the first registries were created in the USA: the Cleveland Vascular Registry was founded by Norman Hertzer. A registry of even greater clinical importance and with high scientific production was the Vietnam Vascular Registry, created by Norman Rich. This registry was initiated in 1966 with documentation and analysis of vascular trauma treated at the American Army Hospital in Vietnam. During this period, Sweden had some registries, namely the Swedish Knee Arthroplasty Register from 1975 and the Swedish Hip Arthroplasty Register from 1979. These registries include indications for surgery and have been of great practical importance, in particular for evaluating the performance of various types of prostheses.

\section{》) It was agreed to register all patients who underwent any arterial intervention: open or endovascular}

The first population-based registry in vascular surgery was created in Sweden. Possible differences in outcome after vascular surgery performed at county hospitals versus university hospitals were discussed at an annual Swedish vascular meeting in 1985. One of the main topics of debate was if the larger university hospitals really had better results than the county hospitals. The vascular surgeons working at the district hospitals felt that this attitude that bigger hospitals had better results a priori, were not based on facts but on prejudice. To find out, a group of vascular surgeons, namely Sven-Erik Bergentz, David Bergqvist, Thomas Troëng, Eibert Einarsson and Lars Norgren drafted a proposal for a vascular surgical registry in the southern region of Sweden: the Vascular Registry in Southern Sweden (VRISS). A paper form was created, presented and reviewed by representatives of vascular surgery at the surgical departments in the southern region of Sweden. The form was processed and a preliminary version was tested for 1 month in 1986 before launching the registry in January 1987. The goal of the registry was to measure patient outcome, evaluate the relationship between volume and results, create a basis for healthcare planning and a quality assessment instrument. Furthermore, it aimed to follow the development of new technologies and to serve as a basis for education and research. An important initial issue of debate was which patients/procedures to include in the registry: all patients with a certain diagnosis, all patients undergoing angiography, all amputations, etc. It was agreed to register all patients who underwent any arterial intervention: open or endovascular. In order to include all vascular surgery throughout the southern region, the number of variables became a compromise between the possible (i.e. what most people agreed without the registration becoming too 


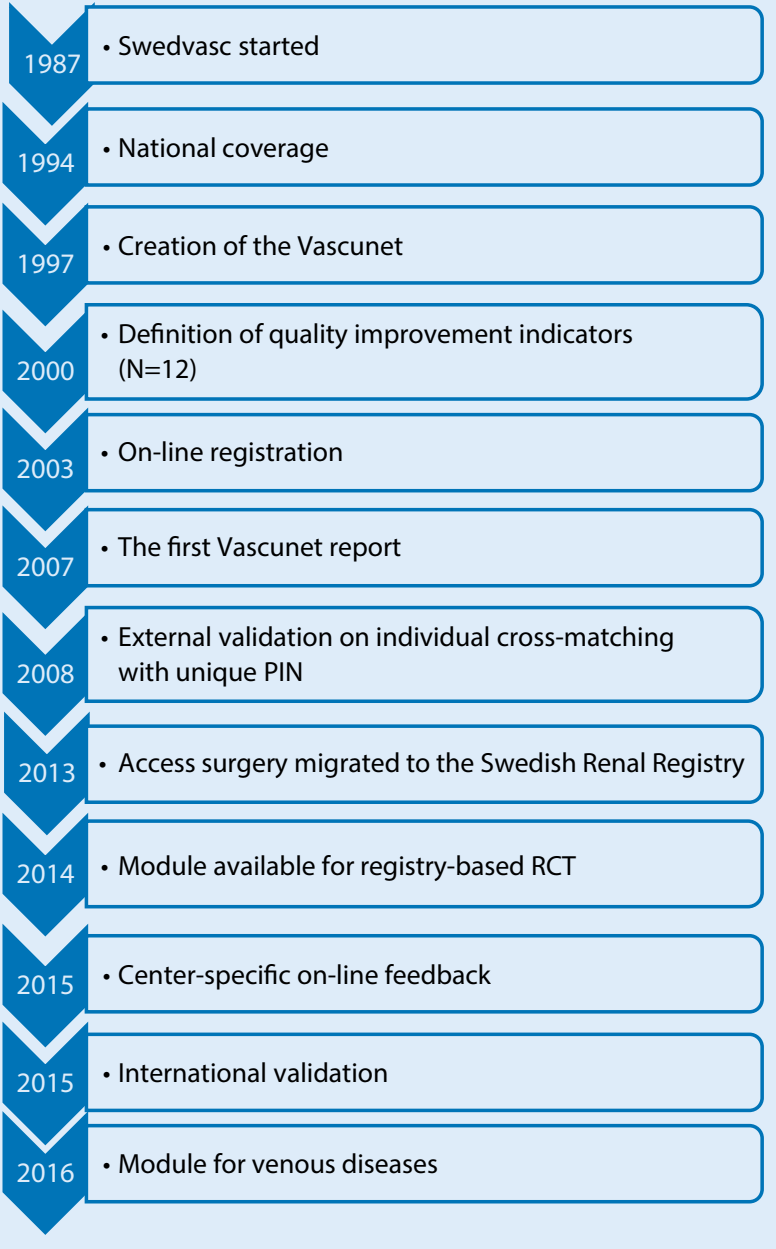

The development of the Swedvasc registry is presented in $\bullet$ Fig. 1.

\section{Benefits of a national vascular registry}

Swedvasc has provided clinicians, healthcare managers and patients with data on clinical care, compliance to evidencebased guidelines, and outcomes for 31 years. Data from the registry are analyzed and summarized in a yearly report. The database is analyzed in March and April for the previous year, thus supplying the vascular surgical community with center-specific data for continuous quality improvement projects. Numbers, types of procedures and outcomes are presented by hospital and on a national level. This provides fast feedback on performances. To further facilitate the use of data for continuous work process management, an automatically generated report (with real-time update) on center-specific outcomes compared to the national results for a set of predefined quality indicators in vascular surgery has been available on login to the Swedvasc webpage for all users since 2015. Furthermore, the on-line reports provide data regarding centers' production and percentage of follow-ups performed. This function is a useful tool for feedback to the vascular team. The Swedish Association of Local Authorities and Regions monitors healthcare quality and efficiency in the 21 Swedish healthcare regions annually by using a set of national performance indicators. For vascular surgery, Swedvasc data are used for the following indicators: time from event to carotid artery procedure, mortality after aortic aneurysm repair and amputation rate after revascularization for peripheral arterial disease.

Data from the Swedvasc registry play an important role in many research projects. Yearly, approximately 10,000-12,000 procedures are registered in Swedvasc, - Fig. 2. The registry provides real-world data in large consecutive cohorts, in an unselected nationwide population. This possibility to assess practice and outcome in a nationwide cohort makes the findings of studies performed in Swedvasc often highly 
Gefässchirurgie 2019·24:21-26 https://doi.org/10.1007/s00772-018-0473-x

(c) The Author(s) 2018

\section{B. Sigvant · K. Mani · M. Björck}

\section{The Swedish vascular registry Swedvasc 1987-2018. 31 years of quality improvement and research}

\section{Abstract}

The Swedish vascular registry, Swedvasc, was created in 1987 as a regional registry and achieved national coverage in 1994. This article describes how the registry developed during those 31 years. The aims of the registry were to enhance quality improvement and research within the field of vascular surgery. The registry was validated on several occasions and in 2015 an independent international validation took place, showing both excellent external (no missing cases) and internal validity (comparing the variables in the registry with case records). The Swedvasc was instrumental in the creation of Vascunet in 1997, the international collaboration of vascular registries in Europe, Australia and New Zealand. Enabling international comparisons of indications, techniques and outcomes has proven to be a great force in quality improvement. This collaboration is now turning global, including the North American registry the Society for Vascular Surgery Vascular Quality Initiative (SVSVQI) and hopefully soon also including the Japanese registry. The Swedvasc is used as an integral part of routine healthcare and over 10,000 procedures are registered annually. This provides clinicians, clinics, health authorities and researchers with realworld data from an unselected nationwide population. Registry data have been used to describe patterns of treatment and outcomes over time and for monitoring quality of care locally, nationally and internationally and for quality improvement projects. The clinical data available in Swedvasc provide an important source not only for assessment and development of healthcare but also for research and over 100 original articles based on Swedvasc data have been published. A randomization module has been included in the registry since 2014 and opens up a new clinical trial paradigm; registry-based randomized clinical trials.

\section{Keywords} Vascular surgical procedures - Quality improvment/trends . Clinical research . Medical audits · Database

\section{Das schwedische Gefäßregister Swedvasc 1987-2018. 31 Jahre Forschung und Qualitätsoptimierung}

\section{Zusammenfassung}

Das schwedische Gefäßregister Swedvasc wurde 1987 als regionales Register gegründet, 1994 war die landesweite Abdeckung erreicht. In diesem Beitrag wird beschrieben, wie sich das Register in diesen 31 Jahren entwickelt hat. Die Ziele des Registers waren die Verbesserung der Qualität und die Forschung auf dem Gebiet der Gefäßchirurgie. Das Register wurde mehrfach validiert, und in einer unabhängigen internationalen Validierung im Jahr 2015 zeigte sich eine ausgezeichnete sowohl externe (keine fehlenden Fälle) als auch interne Validität (Vergleich der Variablen im Register mit Patientenakten). Swedvasc war maßgeblich beteiligt an der Gründung von Vascunet im Jahr 1997, dem internationalen Zusammenschluss von Gefäßregistern in Europa, Australien und Neuseeland. Internationale Vergleiche von
Indikationen, Techniken und Ergebnissen zu ermöglichen, hat sich als eine wichtige Voraussetzung für die Qualitätsverbesserung erwiesen. Diese Zusammenarbeit wird nun global, wenn sie das nordamerikanische Register SVS-VQI (The Society for Vascular Surgery Vascular Quality Initiative) und hoffentlich bald auch das japanische Register mit einschließt. Swedvasc ist ein integraler Bestandteil der Versorgungsroutine, jedes Jahr werden mehr als 10.000 Verfahren registriert. Damit stehen klinisch tätigen Medizinern, Krankenhäusern, Gesundheitsbehörden und Forschern konkrete Daten eines nichtselektierten landesweiten Kollektivs zur Verfügung. Registerdaten wurden verwendet für die Beschreibungen möglicher Therapieund Outcomemuster im zeitlichen Verlauf, für ein lokales, nationales und internationales
Monitoring der Versorgungsqualität und für Projekte zur Qualitätsverbesserung. Die in Swedvasc verfügbaren klinischen Daten stellen eine wichtige Quelle nicht nur für die Beurteilung und Entwicklung des Gesundheitswesens dar, sondern auch für die Forschung: Über 100 Originalarbeiten wurden auf der Basis von Swedvasc-Daten verfasst. Seit 2014 enthält das Register ein Randomisierungsmodul; damit eröffnet sich ein neues Paradigma für Studien: registerbasierte, randomisierte klinische Studien.

\section{Schlüsselwörter}

Gefäßchirurgie · Register · Qualitätsverbesserung · Klinische Forschung · Datenbank generalizable. Weaknesses such as limited precision (internal validity) and completeness (external validity) must always be taken into consideration. The latest extensive validation of the registry took place in 2015 and the registry was found to have a high accuracy, where external validity was $100 \%$ (95\% confidence interval CI 98.8-100\%) for carotid arteries and 98.8\% (95\% CI 96.9-99.5\%) for abdominal aortic aneurysms (AAA) [5]. This validation was undertaken by two non-Swedish experts in an international validation model adding further credibility to the validation process.

Comprehensive clinical data from the registry can be combined with data from governmental registries and thereby provide an important source for research and quality improvement [6-11]. Another advantage is the feasibility of collecting data on rare diseases, which for example, has been done for ruptured popliteal artery aneurysms, mycotic aneurysms and vascular injuries [12-16]. Based on Swedvasc data approximately 110 original articles and $15 \mathrm{PhD}$ theses have been published and almost 200 scientific presentations were performed (• Fig. 3 ). A publication list of all peer reviewed articles based on Swedvasc data is enclosed (Appendix 1 for web publication only). 

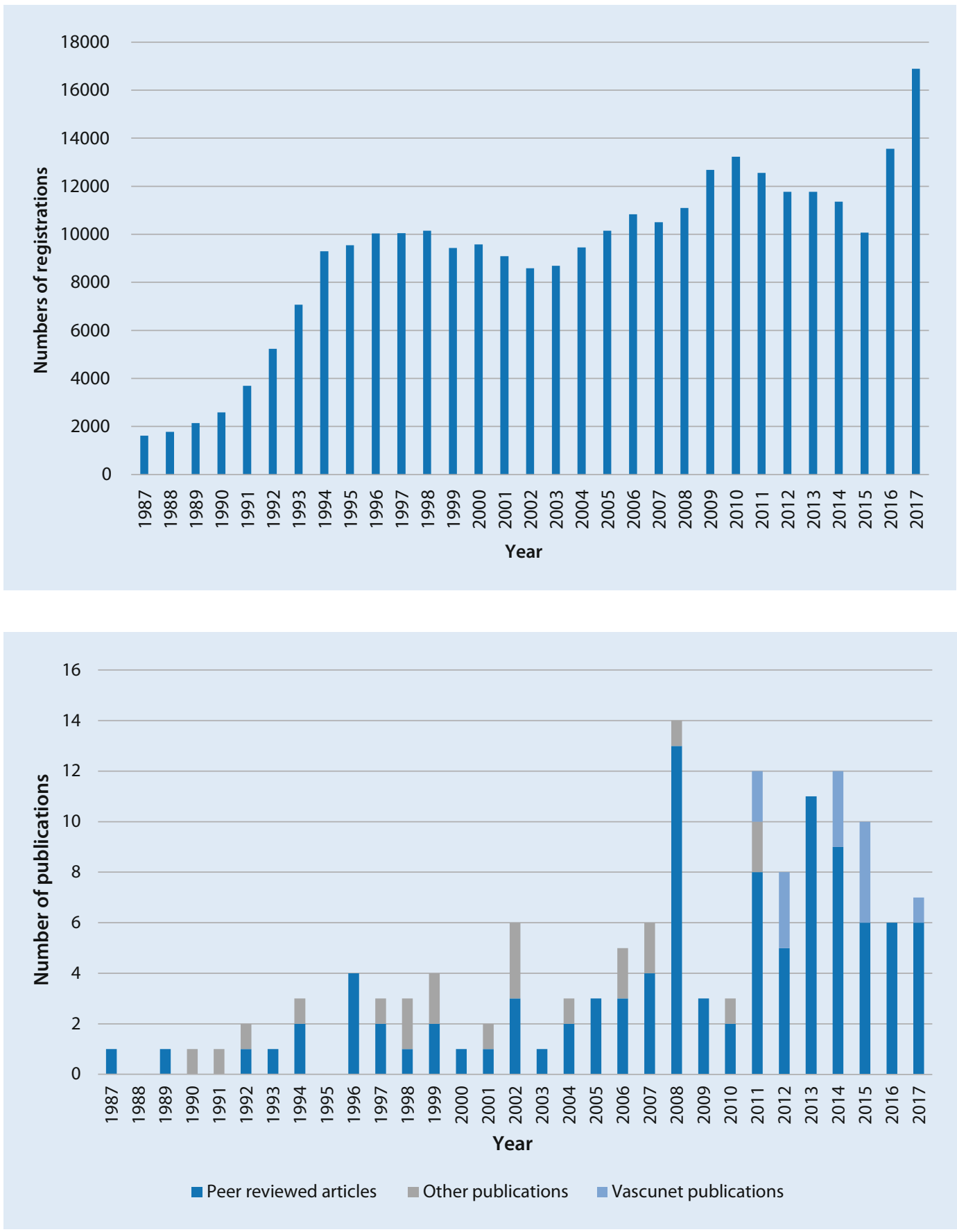

Fig. $2 \triangleleft$ Numbers of registered procedures in Swedvasc during 1987-2017 (from 2016 onwards venous procedures are registered in Swedvasc, resulting in the sharp increase at the end of the reported period)

\section{Registry-based randomized trials-the new paradigm}

Registries have opened up a new clinical trial paradigm; registry-based randomized clinical trials (RRCT), with the TASTE study as a pioneer. In this multicenter, prospective RCT routine thrombus aspiration before percutaneous coronary intervention (PCI) was compared with PCI alone. Thrombus aspiration did not reduce the 3 -day mortality and the European and American guidelines were updated accordingly [17]. There are two main advantages of an RRCT compared to a conventional RCT. Firstly, the results of the treatment of all patients eligible for randomization are presented, which results in four patient groups being presented: randomized treatment $\mathrm{A}$, randomized treatment $\mathrm{B}$, non-randomized treatment $\mathrm{A}$ and non-randomized treatment $\mathrm{B}$. This addresses the problem with selection bias in a very adequate way,
Fig. $3<$ Numbers of publications per year based on Swedvasc data during 1987-2017 
TASTE study cost less than $10 \%$ compared with a conventional RCT. Within the Swedvasc registry there is an ongoing multicenter, prospective RRCT (SwedePAD) where drug-eluting technologies (balloons and stents) are compared to conventional endovascular treatment for peripheral arterial disease (PAD). It is the largest ongoing trial evaluating this new technology. This registry-based trial methodology captures baseline data and key endpoints that are clinically relevant, such as amputation rate for critical limb ischemia and health-related quality of life for intermittent claudication.

\section{International registry collaboration}

Leaders of the Swedvasc registry were active in the creation of the International registry collaboration network, the Vascunet. This international vascular surgical registry network started as an informal collaboration in 1997 with discussions at the annual meetings of the European Society for Vascular Surgery (ESVS). It is now an established subcommittee of the ESVS where more than 20 European and Australasian countries participate. In collaboration with the US Vascular Quality Initiative (the SVSVQI), Vascunet, and device regulators, the transatlantic collaboration named the International Consortium of Vascular Registries (ICVR) has been formed. The Vascunet aims to increase knowledge and understanding of vascular diseases and to promote excellence in vascular surgery, by means of international vascular audit [18]. International registry collaboration and amalgamation of data require a common minimum dataset for vascular registries, as well as common definitions for collected data. The Vascunet has therefore put a significant effort into creating minimum datasets for common vascular surgical procedures in carotid artery disease, aortic surgery and PAD interventions. The recommendations for peripheral revascularization registry data collection were recently created by a modified Delphi approach with on-line interaction within 14 countries among international vascular surgeons and registry mem- bers of the ICVR [19]. The Vascunet and ICVR have additionally performed international benchmarking studies of vascular surgical practice and outcome, identifying important variations in the practice of vascular surgery between countries and regions [20-23]. These benchmarking studies help to identify clinical areas where further studies are required to reach consensus regarding best management, as well as regional variations which may require focused quality improvement efforts.

\section{Practical conclusion}

The Swedvasc registry was created more than $\mathbf{3 0}$ years ago and has significantly contributed to the development of vascular surgery in Sweden. It is difficult to overestimate its importance. The quality of vascular surgical care has progressively increased, changes in management were implemented faster and evaluation of those changes has been possible. The database of the registry has proven to be a powerful research tool and the international collaboration that developed in later years has made it possible to perform comparisons that have shown great variability in the delivery of healthcare. The authors would like to finish by quoting Thomas Troëng, one of the founders of the registry: "A surgeon who doesn't count, doesn't count".

\section{Corresponding address}

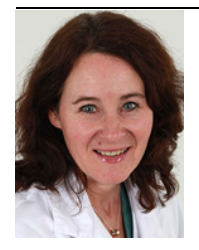

Dr. B. Sigvant, PhD

Department of Surgery, Karlstad Hospital 68580 Karlstad, Sweden birgitta.sigvant@liv.se

\section{Compliance with ethical guidelines}

Conflict of interest. B. Sigvant, K. Mani and M. Björck declare that they have no competing interests.

This article does not contain any studies with human participants or animals performed by any of the authors.
Open Access. This article is distributed under the terms of the Creative Commons Attribution 4.0 International License (http://creativecommons.org/licenses/by/ 4.0/), which permits unrestricted use, distribution, and reproduction in any medium, provided you give appropriate credit to the original author(s) and the source, provide a link to the Creative Commons license, and indicate if changes were made.

\section{References}

1. Bjorck M, Bergqvist D, Eliasson K, Jansson I, Karlstrom L, Kragsterman B et al (2008) Twenty years with the Swedvasc Registry. Eur J Vasc Endovasc Surg 35(2):129-130

2. Jakobsen E, Green A, Oesterlind K, Rasmussen TR, lachina M, Palshof T (2013) Nationwide quality improvement in lung cancer care: the role of the Danish Lung Cancer Group and Registry. J Thorac Oncol 8(10):1238-1247

3. Behrendt CA, Sigvant B, Szeberin Z, Beiles B, Eldrup $\mathrm{N}$, Thomson IA et al (2018) International variations in amputation practice: a VASCUNET report. Eur J Vasc Endovasc Surg 56(3):391-399

4. Norgren L (2018) The Vascunet report on amputations: Does it contribute? Eur J Vasc Endovasc Surg 56(3):400

5. Venermo M, Lees T (2015) International Vascunet validation of the Swedvasc registry. Eur J Vasc Endovasc Surg 50(6):802-808

6. Jonsson $M$, Lindstrom $D$, Gillgren $P$, Wanhainen A, Malmstedt J (2016) Long-term outcome after carotid artery stenting: a population-based matched cohort study. Stroke 47(8):2083-2089

7. Karthikesalingam A, Wanhainen A, Holt PJ, VidalDiez A, Brownrigg JR, Shpitser I et al (2016) Comparison of long-term mortality after ruptured abdominal aortic aneurysm in England and Sweden. BrJSurg 103(3):199-206

8. Karthikesalingam A, Grima MJ, Holt PJ, VidalDiez A, Thompson MM, Wanhainen A et al (2018) Comparative analysis of the outcomes of elective abdominal aortic aneurysm repair in England and Sweden. Br J Surg 105(5):520-528

9. Smidfelt K, Drott C, Torngren K, Nordanstig J, Herlitz J, Langenskiold M (2017) The impact of initial misdiagnosis of ruptured abdominal aortic aneurysms on lead times, complication rate, and survival. Eur J Vasc Endovasc Surg 54(1):21-27

10. Baubeta Fridh $E$, Andersson $M$, Thuresson $M$, Sigvant B, Kragsterman B, Johansson $S$ et al (2017) Amputation rates, mortality, and preoperative comorbidities in patients revascularised for intermittent claudication or critical limb ischaemia: a population based study. Eur J Vasc Endovasc Surg 54(4):480-486

11. Sigvant B, Kragsterman B, Falkenberg M, Hasvold $P$, Johansson S, Thuresson M et al (2016) Contemporary cardiovascular risk and secondary preventive drug treatment patterns in peripheral artery disease patients undergoing revascularization. JVasc Surg 64(4):1009-1017e3

12. Bernhoff K, Bjorck M, Larsson J, Jangland E (2016) Patient experiences of life years after severe civilian lower extremity trauma with vascular injury. Eur J VascEndovasc Surg 52(5):690-695

13. Ravn H,Pansell-FawcettK, BjorckM (2017)Popliteal artery aneurysm in women. Eur J Vasc Endovasc Surg 54(6):738-743

14. Cervin A, Ravn H, Bjorck M (2018) Ruptured popliteal artery aneurysm. Br J Surg. https://doi. org/10.1002/bjs.10953 
15. Sorelius K, Wanhainen A, Furebring M, Bjorck M, Gillgren P, Mani K et al (2016) Nationwide study of the treatment of mycotic abdominal aortic aneurysms comparing open and endovascular repair. Circulation 134(23):1822-1832

16. Wahlgren CM, Kragsterman B (2015) Management and outcome of pediatric vascular injuries. JTrauma Acute Care Surg 79(4):563-567

17. Lagerqvist B, Frobert O, Olivecrona GK, Gudnason T, Maeng M, Alstrom P et al (2014) Outcomes 1 year after thrombus aspiration for myocardial infarction. NEngl J Med 371(12):1111-1120

18. Mitchell D, Venermo M, Mani K, Bjorck M, Troeng T, Debus $S$ et al (2015) Quality improvement in vascular surgery: the role of comparative audit and Vascunet. Eur JVasc Endovasc Surg 49(1):1-3

19. Behrendt CA, Bertges D, Eldrup N, Beck AW, Mani K, Venermo M et al (2018) International Consortium of Vascular Registries consensus recommendations for peripheral revascularisation registry data collection. Eur J Vasc Endovasc Surg 56(2):217-237

20. Beck AW, Sedrakyan A, Mao J, Venermo M, Faizer R, Debus S et al (2016) Variations in abdominal aortic aneurysm care: a report from the International Consortium of Vascular Registries. Circulation 134(24):1948-1958

21. Budtz-Lilly J, Bjorck $M$, Venermo $M$, Debus S, Behrendt CA, Altreuther M et al (2018) Editor's choice - the impact of centralisation and endovascular aneurysm repair on treatment of ruptured abdominal aortic aneurysms based on international registries. Eur J Vasc Endovasc Surg 56(2):181-188

22. Budtz-Lilly J, Venermo $M$, Debus $S$, Behrendt CA, Altreuther M, Beiles B et al (2017) Editor's choice-assessment of international outcomes of intact abdominal aortic aneurysm repair over 9 years. Eur JVasc Endovasc Surg 54(1):13-20

23. Venermo M, Wang G, Sedrakyan A, Mao J, Eldrup N, DeMartino R et al (2017) Editor's choice-carotid stenosis treatment: variation in international practice patterns. Eur J Vasc Endovasc Surg 53(4):511-519

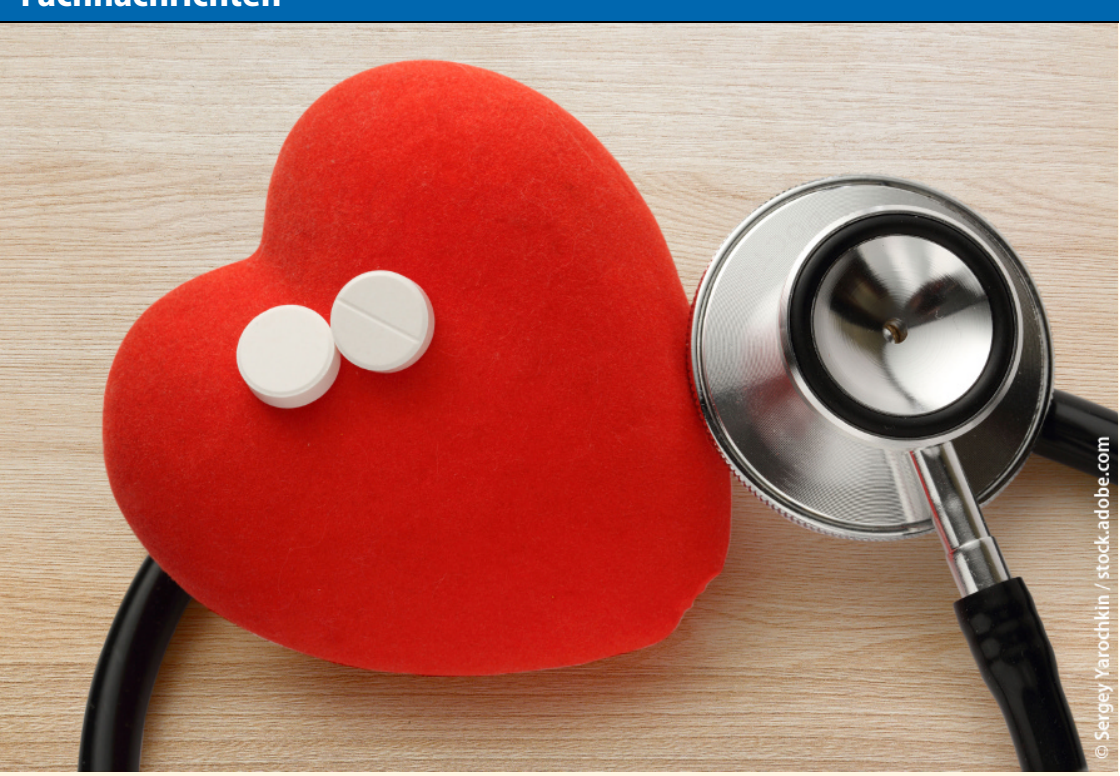

\section{Nutzen und Risiko von Aspirinprophylaxe halten sich bei Diabetespatienten die Waage}

Aspirin kann bei Diabetespatienten, die noch keine kardiovaskuläre Vorerkrankung haben, wirksam Herzinfarkte und Schlaganfälle vorbeugen, aber auch zu starken Blutungen führen. Einen Krebs-protektiven Effekt, wie ihn frühere Studien gezeigt hatten, konnte die aktuelle Untersuchung nicht nachweisen.

Diabetespatienten haben generell ein erhöhtes Herz-Kreislauf-Risiko. Aspirin reduziert nachweislich das Risiko eines neuerlichen kardiovaskulären Ereignisses nach einem Herzinfarkt oder Schlaganfall, und wird bei Patienten mit einer kardiovaskulären Vorerkrankung empfohlen. Die Rolle von Aspirin in der Primärprävention - also bei Menschen ohne bestehende HerzKreislauferkrankung - hingegen ist bisher weniger eindeutig, weil die Substanz auch mit einem erhöhten Risiko starker Blutungen verbunden ist.

„Wir konnten in der aktuellen Studie klar zeigen, dass Aspirin das Risiko kardiovaskulärer Ereignisse wie Herzinfarkte, Schlaganfälle oder Transitorische Ischämische Attacken (TIA) reduziert, aber auch das Blutungsrisiko, insbesondere im Magen-Darm-Trakt erhöht", berichtete in München die Hauptautorin der Studie, Prof. Jane Armitage von der Universität Oxford. „Insofern gibt es also keinen eindeutigen Benefit. Einen Krebs-protektiven Effekt, wie er immer wieder diskutiert wird, konnten wir in dieser Studie nicht nachweisen. Wir werden aber die Studienteilnehmer weiterverfolgen um zu sehen, ob es diesbezüglich langfristig positive Effekte gibt."

Für die ASCEND-Studie wurden zwischen 2005 und 2011 insgesamt 15.480 Patienten mit Diabetes untersucht, die keine kardiovaskuläre Vorerkrankung aufwiesen. Sie erhielten entweder 100 mg Aspirin täglich oder Placebo. Während einer durchschnittlichen Followup-Periode von 7,4 Jahren erlitten 8,5 Prozent der Patienten in der Aspirin-Gruppe ein kardiovaskuläres Ereignis (Herzinfarkt, Schlaganfall oder TIA), in der Placebo-Gruppe waren es 9,6 Prozent. Bei 11 von 1000 Teilnehmern ließ sich also ein solches Ereignis vermeiden. Das entspricht einer relativen Risikoreduktion von 12 Prozent. Dem gegenüber gab es bei 4,1 Prozent der Studienteilnehmer in der Aspirin-Gruppe schwere Blutungen, und bei 3,2 Prozent in der Placebo-Gruppe. Demzufolge hatten 9 von 1.000 Teilnehmern eine Aspirin-bedingte schwere Blutung. Das entspricht einer relativen Risikozunahme von 29 Prozent. Nutzen und Risiko der Aspirinprophylaxe hielten sich die Waage, wie die Studienautoren betonten.

Quelle: Deutsche Gesellschaft für Kardiologie - Herz- und Kreislaufforschung e.V. German Cardiac Society, www.dgk.org 